\title{
Equipment Use in Biology Teaching
}

\author{
Hamiyet Sayan (Corresponding author) \\ Üsküdar University, Istanbul, Turkey
}

Tel: 0-216-400-2222 E-mail: hamiyet.sayan@uskudar.edu.tr

\section{Hatice Mertoğlu}

Science Education Department, Marmara University, Istanbul, Turkey

Tel: 0-216-345-9090 E-mail: hatice.mertoglu@marmara.edu.tr

\author{
Received: May 14, 2020 Accepted: June 14, 2020 Published: June 23, 2020 \\ doi:10.5296/jei.v6i1.17042ＵRL: https://doi.org/10.5296/jei.v6il.17042
}

\begin{abstract}
This paper discusses the use of educational equipment and materials can be used by biology teachers. Science Education has an important role in raising individuals who can adapt to developing world with the 21 st century skills. Within the scope of science education, biology covers information that individuals can make use of in their daily lives. This makes Biology teaching even more important. Teachers assume great responsibilities in the realization of an effective biology teaching. One of these responsibilities is the use of equipment and materials in teaching because the use of equipment in teaching helps with learning the information in an effective, permanent and meaningful way. It is also creating an active and fun classroom environment. Biology teachers should choose suitable equipment for the course, subject, students' level, setting and objectives. They should also be able to develop teaching materials in line with learning outcomes. In addition, the teacher should provide the students with the necessary information about the teaching materials. This paper aims to remind teachers how important using these equipment for teaching and demonstrate that equipment and materials are indispensable facilitators for an efficient and effective Biology teaching. It may help teachers by providing guidance on this issue.
\end{abstract}

\section{Introduction}

In today's world, it is commonly recognized that one of the most efficient way is using information. One of the significant problems in this context is related to how to use information in an efficient way. Raising individuals who know how to access information easier and be realized through effective use of equipment in the classroom in education 
(Köseoğlu \& Soran, 2004).

Given that the $20^{\text {th }}$ century was an industry age and the $21^{\text {st }}$ century is information age, it can be seen that it has been compulsory to raise individuals who, instead of obtaining the information from a single source and studying it, know the ways to access information and can use information in the face of problems and create solution methods. Teaching materials have a distinctive importance for the teachers to design effective and interactive teaching environments for the individuals to gain such qualifications (Şahin \& Yıldırım, 1999). When the $20^{\text {th }}$ and $21^{\text {st }}$ centuries are compared, there are great differences in terms of the competencies that people need in areas such as jobs, citizenship and self-realization. The most important reason for this difference is the emergence of complicated information and communication technologies (Dede, 2009). Recent studies have focused on teaching students the $21^{\text {st }}$ century skills (Larson $\&$ Miller, 2011).

One of the objectives of Science Course curriculum is stated as "By developing the competencies that students have developed during primary school education, to raise individuals who have adopted national and spiritual values, are aware of their rights, fulfil their responsibilities, are productive, contribute to the country's social and cultural development, have self-confidence and self-discipline, have acquired essential verbal, numerical and scientific reasoning and social skills and aesthetic sensitivity they will need in daily life, can use these skills effectively and become healthy life oriented people" (MEB, 2018). As can be understood from this statement, the aim of Science Curriculum is not only to equip students with academic information but also to raise them as versatile, social, active and productive individuals.

Today, in many countries of the world, Science Course is taught as an essential course. As being an essential course in the programs it has a big importance of teaching of science education. Countries emphasize science education not only educate young generations in accordance with the requirements of the century and to raise scientists but also to get them to gain daily life skills, to improve their ways of thinking, and to develop their problem-solving skills (Ekes, 2001). In this context, the importance of biology teaching can be understood better.

Science covers the most important areas that require information and comprehension. Especially through Biology, students can make sense of their own and families' development, subjects such as nutrition and health, and many important events (such as...) and developments occurring in their environment and in the world. Biology is an essential part of education for everyone. Biology teaching should be able to reflect the elements of this field and its interesting features. Students should actively participate in the subjects, perform experiments and learn through making associations with daily life (Ohlsson \& Ergezen, 1997). In biology teaching, which has an important place in science education, it is of utmost importance to create a learning environment in which students can comprehend and enjoy learning biology (Yalmanc1, 2016).

In biology teaching, in the classroom or in the laboratory, creating a multi-faceted environment in order for an effective teaching to take place is important in terms of 
teacher-student interaction and communication. The essential elements for creating a multi-faceted environment are equipment. While equipment use in biology teaching cannot be limited in a classroom, it also covers a wide area that addresses the nature in a broader sense. This study is a literature review as a research. The literature and education programs are examined. The necessity of equipment use for teaching biology and how teaching materials are prepared is introduced.

\section{The Necessity of Using Equipment in Education}

Equipment in education is used in order to support and enrich teaching and to facilitate and make learning effective. Educational equipment cannot be considered independently from other elements of teaching-learning process. Therefore, it is not possible to mention a single piece of equipment that can be used in all teaching and learning situations. However, some equipment can be more effective in the teaching and learning certain subjects in comparison to other equipment. The benefits of using equipment in education can be listed as follows (Yalın, 2003; Demirel et al., 2002).

$\checkmark \quad$ It makes abstract situations tangible.

$\checkmark \quad$ It enhances interest, motivation and attention.

$\checkmark \quad$ It saves time.

$\checkmark \quad$ It makes it possible to do safe observations.

$\checkmark \quad$ It enables to provide consistent contents in different periods.

$\checkmark \quad$ It helps with meeting individual needs.

$\checkmark \quad$ It can be used repetitively.

$\checkmark \quad$ It enables effective learning by simplifying the content.

$\checkmark \quad$ It facilitates remembering.

According to the results of a study conducted by Philips in Texas University, USA, when the time factor is taken as a constant, the percentages of remembering is as follows (Cited by Demirel, 2002):

People remember $10 \%$ of what they have read, $20 \%$ of what they have heard, $30 \%$ of what they have seen, $50 \%$ of what they have both seen and heard, $80 \%$ of what they have seen, heard and said, and $90 \%$ of what they have seen, heard, touched and said. As can be understood from that study, equipment is needed for the things learned to be remembered.

Equipment is one of the elements that play a role in the use of educational technology. The teachers, the equipment and the material play different effective roles. Using the equipment randomly in teaching will not provide any benefits as well as wasting time and efforts. Therefore, it is necessary to heed some criteria while using equipment in education. These criteria are stated as suitability for the purpose, accuracy, suitability for the students, attractiveness, practicality, durability and simplicity (Vural, 2004). 
Use of equipment in education plays an important role in the success of the program by preparing an effective classroom environment and helping students to achieve the objectives specified in the program (Karamustafaoğlu, 2006). All tools, equipment and resources used in the development of students' knowledge, skills, attitudes and values are called teaching materials. Today, in creating modern, multimedia in-class learning environments, visual and aural devices come to the fore. For this reason, learning environments which comprise of visual and aural devices that appeal to more than one sense organs should be established so that permanent learning could be achieved (Yaşar, 2004).

Nowadays, with the spread of inclusive education, adaptations and preparations to be made for the students with special needs are on the agenda. The equipment that will be used in the classrooms gains more importance so that students of inclusive education can comprehend science concepts better. Teachers should design teaching materials to facilitate students' learning and should be able to adapt his/her strategies, teaching equipment and lesson plans in accordance with the needs of students. Particularly students with seeing impairment are faced with many challenges related to materials in science courses (Sabzali et al., 2017). Thus, using equipment and materials in the classrooms will contribute not only to students with normal development but also to the participation and learning of the students of inclusive education.

As discussed in the abstract section, the contribution and necessity of equipment in education are too obvious to be debated. Nevertheless, it is also necessary to act in accordance with scientific knowledge regarding the use of equipment and to pay attention to the specific situations of teaching environments.

\section{The Specific Aspects of Biology as a Discipline}

There are various visual methods and techniques employed at each stage of biology teaching. Supporting these methods and techniques with biology equipment is extremely important in terms of students' associating their current knowledge with newly learned information, revealing the connections and transitions between concepts, in other words, appealing to visual memory. Supporting biology education with equipment enables the applied program to be student-centred rather than teacher-centred, and students can learn by not only by hearing but also by seeing, doing, experimenting and investigating. Thus, information learned this way will be permanent and used in producing solutions to the problems faced with in daily life.

Alkan (1998) lists the general objectives of enhanced science education as follows:

(1) Improving scientific thinking skills;

(2) Developing methodology knowledge and skills;

(3) Creating interest and awareness towards science subjects;

(4) Developing attitudes and behaviors respecting and valuing scientific research and results; 
(5) Protecting and using natural environment, social environment and resources smartly; developing knowledge and skill habits.

It is necessary to use new technologies so as to increase achievement in science courses, to develop reasoning skills, to help discover knowledge, to improve problem-solving skills, and to let them use knowledge by keeping the students away from dangerous and hard-to-achieve situations in daily life.

The specific aspects of Biology as a discipline of science can be summarized as follows:

(1) The phenomena and events of interest: They study the structures of living organisms, their relationship with themselves and their environment, and the development and evolutionary history of individuals from birth to death.

(2) Questions that are tried to be answered: Since Biology is a scientific discipline, the questions that are answered are of scientific quality and are described empirically. These can be related to the questions of "what" and "how."

(3) Techniques used in answering the questions: As in other scientific fields, in Biology, experts make observations, classifications and speculations, identify problems, develop hypotheses and test them.

(4) Resources that are developed and applied: Each field of science has its own specific concepts. The concepts included in Biology has specific meanings which can be understood by experts in the field.

(5) Inter-disciplinary communication related to the discipline: In proper situations, Physics, Chemistry and Mathematics terminology can also be used in Biology (Alkan, 1998).

Although biology laboratories are places where things are proven, in a world of innovations that is continuously developing, they have also turned into centers where people can learn about a discovery or the ways of obtaining scientific knowledge. Laboratory work affects reasoning, critical thinking, understanding science, processing skills and hand skills. A science laboratory enables students to use knowledge, develop a general concept, identify a new problem, explain an observation and make decisions. For this reason, the laboratory is a part and in the focus of Science education. The results of many studies conducted on Science education indicate that education provided with laboratory experiments yields more successful outcomes. In studies conducted on Biology, Chemistry, and Physics both on a national and international scale, it has been determined that when students receive Science education through laboratory experiments, they are more successful both cognitively and affectively (Baştuğ et al., 2002).

Concepts are abstract ideas. Concept education is provided in order for certain concepts to form in students' minds. Therefore, concepts need to be concretized before they are taught. For this purpose, some graphic materials such as meaning analysis tables, concept networks and concept maps (Turgut et al., 1997).

In recent years, approaches to educations have been changing, and it has been emphasized 
that classes held only in the classroom are not adequate (Dori \& Tall, 2000). Since Biology subjects include abstract concepts, using visual material will be effective in Biology teaching. As the subjects of Science course are comprised of phenomena and events we observe and experience in daily life, environments outside the school should also be utilized. For example, botanical gardens, zoos, parks, gardens, museums, aquariums and science centers etc. are places which can be used in the teaching of Biology subjects. As Şen (2019) also stated, learning environments can now be various venues outside the school. Due to the fact that learning outside the school is based on educational programs in terms of content, it complements, enriches and contributes to formal education. Melber (2006) also argues that thanks to learning outside the school, students learn the subjects in an easier way. In a study carried out on the activities performed outside the school with Science teacher candidates, Mertoğlu (2019) reports that the teacher candidates expressed that they still had some science subjects they still did not know or they had not completely grasped (Physics) and that the activities reinforced what they already knew (Biology). In a study by Sarığlan and Küçüközer (2017), it is stated that educational activities done outside the school environment had a positive effect on students' permanent learning.

\section{The Necessity of Using Equipment in Biology Education}

It is obvious that the necessity of using equipment in education and teaching is also valid for Biology education. Biology education is essential for life. It has been determined that although teachers know the importance of Biology, students are not aware of this significance (Gürbüz \& Sülün, 2004).

The field of Biology, which is of vital importance for life, needs to get more support in education in this sense. On the other hand, it has been revealed that students learned Biology course more easily by using computers and technology, and that equipment-rich environments promote students' motivation and contributes to success (Yildirım \& Kete, 2002).

In Biology education, many equipment ranging from the simplest writing board to the most advanced electron microscope are provided as accessories to teaching. The more the number of sense organs are involved in Biology education, the better and more permanent the learning will be. What we learn best is what we achieve by ourselves.

There are various methods and techniques employed at each stage of biology teaching that appeal to both hearing and seeing. These methods and techniques are extremely important in terms of students' associating their current knowledge with newly learned information through biology equipment, revealing the connections and transitions between concepts, in other words, appealing to visual memory (Bahar, 2004).

As one of the teaching equipment in Biology teaching, models play a key role in the interpretation of science and help to understand complex concepts easily. Besides, they support students in producing new and creative ideas. In the study conducted by Stohrr Hunt, a significant difference was found in favor of the activities in which hand skills were used (Ünal et al., 2001). Models are the equipment that can be used the most effectively in biology 
teaching. The materials that teachers use in educational environments help them to establish communication with students. It is doubtless that the communication established by the teacher in learning is very important (Aydın \& Yel, 2016).

One of the most challenging phases in Biology teaching process is the selection and design of teaching equipment. Equipment use has a wide range of utilization in Biology teaching. Selecting the most useful equipment for a specific subject is very important in biology education. Teaching Biology without equipment and not using the opportunities provided by the equipment seems almost impossible in Biology teaching.

\section{Equipment and Materials Used in Biology Teaching}

Equipment in Biology teaching can be functional by complementing each other. They can be categorized as visual equipment, aural equipment and both visual and aural equipment. A categorization according to primary groups can be as follows:

Written materials: They are the most used materials used in educational environments. Written materials are easy to be accessed and carried (Course textbooks, supplementary books, magazines, newspapers, guides, brochures, teacher handbooks etc.).

Pictures and graphs: They are the most widely teaching materials used in making the verbal messages meaningful and concrete for students (maps, globes, film strips, slides, teaching boards and graphs).

Realia and models: These are the use of real objects and models for teaching purposes (Bringing different species of plants into the classroom or inviting an expert on a specific subject to class, body and organ models, cross-section of a leaf etc.).

Overhead Projector Transparencies: They are the materials which were used recently.

Visual and aural devices: radio, voice tapes, CD, computer, VCR, smart board, tablet and telephones are among these materials.

Projectors: OHP, slide projector, tablets, smart boards

Television programs and videos: They are the materials through which the events and objects from real life are brought into classroom environment in the most realistic way.

Computer software and internet: They are the materials which provide the highest communication with students. They are very effective in drawing the attention of students, presenting information, having students do exercises and repetitions, providing feedback and assessing students' performance. Visual and audio features can be used in combination (sound, picture, motion pictures, and animations). Today internet is full of materials for using in science teaching. If it is chosen well, they can really be useful on students' learning.

Other equipment: Writing board, revolving boards, individual learning sets, CDs, package software, collections can be counted in this category. Smart Boards and Smart Phones must be mentioned among today's equipment.

As a result of detailed review of Biology curriculum and the literature, the following table 
regarding the equipment that can be used within the scope of Biology Course has been accessed:

\begin{tabular}{|c|c|}
\hline Biology Subjects & Equipment \\
\hline Scientific problem & Concept maps \\
\hline Classification & Posters, realia, concept maps, documentaries, Internet technologies \\
\hline Ecosystem & $\begin{array}{l}\text { OHP and transparencies, computer presentation, documentaries, Internet } \\
\text { technologies }\end{array}$ \\
\hline Nutrition types & Concept maps, pictures and documentaries, Internet technologies \\
\hline Population & Figures, graphs, documentaries, Internet technologies \\
\hline Organic molecules & Models, figures, graphs, experimental equipment, Internet technologies \\
\hline ATP & Models, posters, Internet technologies \\
\hline Cell division & Computer animations, slides, models, Internet technologies \\
\hline Matter exchange & Experimental equipment, computer animations, Internet technologies \\
\hline Cell & Posters, slides, models, Internet technologies \\
\hline Tissues & Posters, slides, Internet technologies \\
\hline Transport system & Models, computer animations, transparency and OHP, Internet technologies \\
\hline Respiratory system & Posters, models, experimental equipment, Internet technologies \\
\hline Digestion system & Posters, models, experimental equipment, Internet technologies \\
\hline Excretory system & Posters, models, experimental equipment, Internet technologies \\
\hline Skeleton and muscle system & Posters, models, experimental equipment, Internet technologies \\
\hline Endocrine system & $\begin{array}{l}\text { Posters, models, experimental equipment, graphs, figures, Internet } \\
\text { technologies }\end{array}$ \\
\hline Nervous system & Posters, models, experimental equipment, Internet technologies \\
\hline Sense organs & Posters, models, Internet technologies \\
\hline Ruling molecules & Models, graphs, figures, Internet technologies \\
\hline Protein synthesis & Computer animation, slides and OHP, Internet technologies \\
\hline Photosynthesis & Posters, experimental equipment, Internet technologies \\
\hline Respiration & Posters, experimental equipment, Internet technologies \\
\hline Reproduction and development & Transparencies, OHP, documentaries, Internet technologies \\
\hline Inheritance & $\begin{array}{l}\text { Experimental equipment, transparencies and OHP, documentaries, Internet } \\
\text { technologies }\end{array}$ \\
\hline
\end{tabular}

As can be seen in the table above, computers and Internet technologies are used in almost every subject today. One of the issues that teachers should pay attention while using 
computer-assisted biology teaching is the approach adopted by the teacher. Using the computer in class in line with behavioral approach would only mean replacing the conventional book with the computer. In this case, since it is the teacher who uses the computer, only the teacher is actively engaged. In contrast, computer should not be a "savior" in teaching. According to structural approach, computer is a tool that helps students to make sense of information and to be active in forming to create their own knowledge. Some of the software that are widely used in recent years in our country are not different from textbooks. They can be thought as the electronic form of the textbooks. For this reason, in relation to the subject of the course and the features of the software, either research and experiment should be performed through computers or research and observations performed must be processed by students with appropriate software (Ekiz, 2011). The way computers that are used in conjunction with smart boards in almost all classrooms as a result of developing technology serve this purpose is a controversial issue.

\section{Equipment Used for Special Purposes in Biology Education}

Biology teaching requires creating a technology specific to its purposes. As its vital importance increases, the teaching technology of the field gains a wide scope. Therefore, the equipment and objects that are used within the scope of Biology Education Technologies are determined specifically. These tools can be computers, software, models, samples, transparencies, shapes, slide projectors, film strips, figures, written-printed materials, audio devices, radio and cassettes, TV, VCR, smart boards and telephones, Internet technology devices. Group works, projects and experiments are widely used in Biology teaching. In addition, writing activities can also be used as a way of effective learning. Problem-solving, which requires an inter-disciplinary approach, is one of the frequently used methods. In relation to these methods, the most frequently used equipment can be listed as follows (Ohlsson \& Ergezen, 1997):

Laboratory equipment: Experiment tube, tube-holder, cork stopper, dropper, drying paper, filter paper, lame, lamella, pipettes $(1,5,10 \mathrm{ml})$ Pasteur pipette, clamp, spatula, bistoury, razor, syringe, sterile syringe, Bunsen burner, tripod, asbestos, pincers, beaker, measuring cylinder, petri dish, Erlenmeyer flask, jar, cone, magnifying glass, thermometer, chronometer, transparent ruler, $\mathrm{pH}$ paper, sugar test paper, red and blue litmus paper, cotton, mortar, dissection basin, dissection syringe, stative leg, stative rod, clamp, rubber pipe, glass pipe, cellophane pipe (intestines), sweep net, toothpick, scissors, tape, sticker, glass pen, aluminum folio, white paper, colored construction paper, wire, thread, knife, packaging rubber, plastic cup, pot filled with soil, plastic bag, newspaper pages, paper towel, straw, screw (Yaman \& Soran, 2000).

Hardware: Light microscope, stereo microscope, autoclave, sterilizer, drying oven, $\mathrm{pH}$ meter, water bath, television, Video, OHP (and transparencies), slide machine (slides), cassette player (cassettes) (Yaman and Soran, 2000).

Chemicals: Phenol red, hydrochloric acid, methyl alcohol, iodine, biuret, Benedict solution, Fehling solution, ether, manganese dioxide (powder), hydrogen peroxide, methylene blue, ethyl alcohol, toluidine blue, nitric acid, methyl cellulose, pepsin, pancreatin, sodium 
hydroxide, bile salt, petroleum ether, acetone, Giemsa (or Wright) paint, starch, glucose, beer yeast (Yaman \& Soran, 2000).

Models: DNA model, skin section, tooth, hand and kidney section, nose, eye, foot, larynx, excretion system, head section, cell, heart, liver section, intestines section, visceral organs (male and female), ear, skeleton, jaws, leaf horizontal section, trunk horizontal section, flower, leaf, root section are taken as basis (Yaman \& Soran, 2000).

\section{Principles of Teaching Materials Preparation}

In addition to all examples, teachers who can use the available equipment and materials choosing the necessary ones consciously should have the skills to prepare and develop materials suitable for the situation and the students when necessary. However, this process should not be handled haphazardly. Some basic principles should be observed. These principles can be listed as:

(1) Teaching materials should be simple, plain and comprehensible.

(2) Teaching materials should be chosen and prepared in accordance with the learning outcomes of the lesson.

(3) Teaching materials should include important and brief information rather than all the information related to the subject of the lesson.

(4) Visuals to be included in teaching materials (picture, graph, color etc.) should be used to emphasize the important points of the material, and overuse should be avoided.

(5) The written texts and visual-audio elements used in teaching materials should fit the pedagogical features of the students and be consistent with the students' real lives.

(6) Teaching materials should give students opportunity to do exercise and practice.

(7) Teaching materials should reflect the real life as much as possible.

(8) Teaching materials should be appropriate for the access and use of each student.

(9) Teaching materials should be simple for students to use, not for teachers to use easily.

(10) Teaching materials to be used again over time should be durable and they should not be damaged by being used only once.

(11) Teaching materials prepared should be flexible enough to be improved and updated easily (Şahin \& Yıldırım, 1999).

\section{Discussion and Suggestions}

In order to carry out Biology teaching in the classroom and the laboratory in an effective manner, a multi-media environment which includes and arranges the equipment and materials should be created. This arrangement is very important in terms of teacher-student interaction and communication.

Use of equipment is as old as human history. Just like today, in the first ages, human beings 
used equipment in order to meet their needs and survive, as well as for training purposes. All opportunities provided by science and technology should be utilized in order to improve the quality of education, to ensure that students gain effective and permanent knowledge, and to share today's rapidly changing and developing knowledge with students (Yesler, 2007).

In recent years in our country, modern technological tools such as interactive (smart) board and tablet computers are being widely used in schools, and the use of technological equipment in teacher training has gained importance (Tekinarslan et al., 2015). However, in several studies, it has been reported that teachers (Türel, 2012; Devecioğlu \& Kaymakç1, 2014; Tekinarslan et al., 2015) and students (Tekinarslan et al., 2015) do not possess enough knowledge and skills in terms of using smart boards.

In a study conducted by Yesler (2007), it has been stated that teachers' access to the available equipment at school whenever they want, and the properties of these equipment being updated to the newest technology affect teachers' use of teaching equipment positively. As Kazu and Yesler (2008) stated, using teaching equipment in class both renders the lessons effective and fun by eliminating monotony and contributes to the successful implementation of education programs. Therefore, it is of utmost importance for the laboratories of schools to be equipped in terms of tools and equipment.

The subjects of biology are based on examination, observation, research and experimenting. Biology teachers should emphasize laboratory work for permanent learning by doing and experiencing to take place. Biology laboratories are the places where students learn actively by doing and experiencing (Alkan, 1998).

As it is known, there is no one single learning method suitable for everyone. When the number of equipment in teaching is increased in accordance with learning outcomes, does it mean that a perfect method suitable for everyone at all levels has been designed? If this method is not suitable for some of the students, what could the reasons be?

All teachers should base their teaching programs on the principle of students' different ways of learning. Especially in ensuring the learning outcomes of Biology Course, they should be able to critically consider the effects of using a variety of equipment within the wide spectrum specific to Biology on students' performance. Furthermore, Biology teachers should know the technical structure, working systems and features of the equipment and develop their skills in using them.

Use of equipment in Biology education is very effective in students' gaining cognitive, affective and psychomotor behaviors. Particularly during laboratory works, affective and psychomotor gains come to the fore. It has been stated that the exotic atmosphere of the laboratory, the smell od acids and bases in the environment, the presence of some experimental tools, or animal and plant samples in some laboratories can motivate students and stimulate their creativity and discovery skills (Bahar, 2003). However, as building an exotic laboratory is costly, it needs effective experience.

On the other hand, one of the most important elements or education process is assessment and evaluation. Thanks to laboratory opportunity and various equipment provided by Biology, 
both Biology teachers and students have the advantage of measurement of kinesthetic properties as well as classical assessment and evaluation dimension.

In many research findings, it has been determined that:

(1) Laboratory sessions are necessary in Biology education, but they are not implemented in sufficient amounts (Ekici, 2002).

(2) There is not enough laboratory equipment in our high schools as they are expensive and hard to procure (Akaydın, Güler, \& Mülayim, 2000).

(3) Teachers lack the necessary knowledge regarding laboratory equipment.

(4) Teacher tend to teach the subjects theoretically and avoid experiments and similar activities as it is not mandatory to these activities.

(5) Teachers should attend in-service training and they should be informed about recent developments through various publications, so that they can have enough knowledge of experiments and equipment.

(6) As the primary teaching method of Biology is based on observation and experiment, both laboratory work and environmental practices and field trips should be emphasized in education (Yaman \& Soran, 2000).

According to the results of research carried out, it is reported that although the majority of science teachers see laboratory works and experiments as an indispensable element of science teaching, they do not allocate much time for experiments in their classes, and they put forward the rationale behind this situation as little knowledge of laboratory equipment or lack of enough equipment in the laboratory, so they have to do demo experiments due to lack of equipment. However, teachers should have the skills to design experiments by using simple equipment or complicated laboratory materials (Cefni \& Ayvac1, 2006). Thus, for an effective implementation of biology education, it is important to emphasize laboratory practices during undergraduate education, to get the teacher candidates to familiarize themselves with laboratory equipment and to improve their experiment skills.

In a study conducted by Değirmenci and Doğru (2019), the realization of the learning outcomes of the unit titled "Let's Know the Matter" in terms of students was investigated. It was determined in the research that although the school had enough equipment, science teachers preferred practices in the classroom environment. In the interview held with one teacher, the teacher stated that s/he most frequently used computers, the Internet and laboratory; however, in the observations made, it was identified that s/he used such equipment as textbook, board, tables, camping cylinder, pan, strainer etc.

The necessary in-service and pre-service training should be provided to teachers and teacher candidates so that they can adopt use of teaching equipment. Especially for the Biology education, which has a special place in science teaching, practices during lessons regarding the introduction and use of teaching equipment should be carried out.

Finally, training programs should be organized in order to increase biology teachers' 
knowledge and competence in terms of equipment use and material development. Booklets or e-bulletins that will guide teachers in this issue can be provided.

\section{References}

Akaydın, G., Güler, M. H., \& Mülayim, H. (2000). Liselerimizin biyoloji laboratuvar araç ve gereçleri bakımından durumu. Hacettepe Üniversitesi Eğitim Fakültesi Dergisi, 19, 1-4.

Alkan, C., \& Kurt, M. (1998). Özel ögretim yöntemleri. Ankara: Anı Yayıncılık.

Bahar, M. (2001). Biyoloji eğitiminde kavram haritalarının kullanımı. Abant İzet Baysal Üniversitesi Eğitim Fakültesi Dergisi, 1(1), 25-40.

Bahar, M. (2003). Fen bilimlerinde etkin öğrenme modeli ve uygulamaları, Niğde Üniversitesi Ë̆itim Fakültesi Dergisi, 2.

Baştuğ, A., Çıkılı, Y., Yalçın, P., \& Polat, R. (2002). Öğrenci sayısının Fen Laboratuarı dersinin laboratuar hedeflerini gerçekleştirilme düzeyi üzerine etkisi. V. Ulusal Fen Bilimleri ve Matematik Eğitimi Kongresi, Cilt I, Ankara.

Çepni, S., \& Ayvacı, H. Ş. (2006). Laboratuvar destekli fen ve teknoloji öğretimi. Ed. Salih Çepni. Kuramdan uygulamaya fen ve teknoloji öğretimi içinde (pp. 158-188, 5 Bask1). Ankara: Pegem Yayıncılık.

Dede, C. (2009). Comparing frameworks for 21st century skills. Retrieved from http://sttechnology.pbworks.com/f/Dede_(2010)_Comparing\%20Frameworks\%20for\%2021st $\% 20$ Century\%20Skills.pdf

Değirmenci, A., \& Doğru, M. (2019). İlkokul 4. sınıf fen bilimleri dersi öğretim programı maddeyi tanıyalım ünitesi kazanımlarının gerçekleşme düzeyinin değerlendirilmesi. Gazi Ĕ̆itim Bilimleri Dergisi, 5(1), 102-121. https://doi.org/10.30855/gjes.2019.05.01.006

Demirel, Ö., Seferoğlu, S., \& Yağcı, E. (2002). Öğretim Teknolojileri ve Materyal Geliştirme. Ankara: Pegema Yayıncılık.

Devecioğlu, Y., \& Kaymakçı, R. (2014). Akıllı tahta kullanımı konusunda öğretmenlerin düşünce ve ihtiyaçları. Eğitim Teknolojileri Araştırmaları Dergisi, 5(1), 1-15.

Ekici, G. (2002). Biyoloji öğretmenlerinin lavaratuvar dersine yönelik tutum ölçeği (BÖLDYTÖ). Hacettepe Üniversitesi Eğitim Fakültesi Dergisi, 22, 62-66.

Ekiz, D. (2001). Illköğretimde fen bilimi öğretimi ve ögrrenimi. Trabzon: Derya Kitabevi.

Gürbüz, H., \& Sülün, A. (2004). Türkiye'de biyoloji öğretmenleri ve biyoloji öğretmen adaylarının nitelikleri. Milli Eğitim Dergisi, 161(31), 192-204.

Karamustafaoğlu, O. (2006). Fen ve teknoloji öğretmenlerinin öğretim materyallerini kullanma düzeyleri: Amasya ili örneği. Atatürk Üniversitesi Bayburt Ĕgitim Fakültesi Dergisi, 1(1), 90-101.

Kazu, H., \& Yeşilyurt, E. (2008). Öğretmenlerin öğretim araç-gereçlerini kullanım amaçları. 
Fırat Üniversitesi Sosyal Bilimler Dergisi, 18(2), 175-188.

Köseoğlu, P., \& Soran, H. (2004). Biyoloji öğretmenlerinin araç-gereç kullanım yeterliliklerine ilişkin görüşleri. Hacettepe Üniversitesi Eğitim Fakültesi Dergisi, 27, 189-195.

Larson, L. C., \& Miller, T. N. (2011). 21st century skills: Prepare students for the future. Kappa Delta Pi Record, 47(3), 121-123. https://doi.org/10.1080/00228958.2011.10516575

MEB. (2018). Fen bilimleri dersi öğretim programı. Ankara, Turkey.

Ohlsson, B., \& Ergezen, S. S. (1997). Biyoloji Öğretimi. YÖK/Dünya Bankası Milli Eğitimi Geliştirme Projesi Hizmet Öncesi Öğretmen Eğitimi, Ankara.

Tekinarslan, E., Top, E., Gürer, M. D., Yıkmış, A., Ayyıldız, M., Karabulut, A., \& Savaş, Ö. (2015). Etkileşimli tahtada çoklu-ortam nesneleriyle yapılan öğretimin öğretmen adaylarının zenginleştirilmiş içerikle öğretime yönelik tutumlarına etkisi. Eğitim Teknolojisi Kuram ve Uygulama, 5(2), 20-38. https://doi.org/10.17943/etku.68000

Türel Y. K. (2012). Öğretmenlerin akıllı tahta kullanımına yönelik olumsuz tutumları: problemler ve ihtiyaçlar. Illköğretim Online, 11(2), 423-439.

Turgut, M. F., Baker, D., Cunningham, R., \& Piburn, M. (1997). Illkögrretim fen ögrretimi. Ankara: YÖK/Dünya Bankası Milli Eğitimi Geliştirme Projesi Hizmet Öncesi Öğretmen Eğitimi.

Ünal, M., Akıncı, Ş., \& Şahin, F. (2000). Biyolojik Kavramların Öğretilmesinde Modellerin Rolü: Mitoz Bölünme. IV. Fen Bilimleri Eğitimi Kongresi (6-8 Ekim 2000) Bildiriler Kitabi. MEB Basımevi, Ankara.

Vural, B. (2004). Eğitim-öğretim teknoloji ve materyal kullanımı, İstanbul: Hayat Yayıncılık.

Yalın, H. İ. (2003). Öğretim teknolojisi ve materyal geliştirme, Ankara: Nobel Yayın Dağıtım.

Yaman, M., \& Soran, H. (2000). Türkiye'de ortaöğretim kurumlarında biyoloji öğretiminin değerlendirilmesi. Hacettepe Üniversitesi Eğitim Fakültesi Dergisi, 18(18).

Yaşar, O. (2004). İlköğretim sosyal bilgiler derslerinde görsel materyal kullanımı ile coğrafya konularının eğitim ve öğretimi. Milli Eğitim Dergisi, 163.

Yeşilyurt, E. (2007). Öğretim araç-gereçleri kullanımına etki eden faktörler. Education Sciences, 2(4), 300-312.

Yıldırım, A., \& Kete, R. (2002). Biyoloji derslerinde verimlilik ve teknoloji kullanımı. V. Ulusal Fen Bilimleri ve Matematik Kongresi Bildiriler Kitabı. Ankara: Milli Eğitim Basımevi. 


\section{Copyright Disclaimer}

Copyright for this article is retained by the author(s), with first publication rights granted to the journal.

This is an open-access article distributed under the terms and conditions of the Creative Commons Attribution license (http://creativecommons.org/licenses/by/3.0/). 